Policing Europe 


\section{Also by Bill Hebenton and Terry Thomas}

B. Hebenton and T. Thomas, Criminal Records: State, Citizen and the Politics of Protection

T. Thomas, The Police and Social Workers 


\title{
Policing Europe
}

Co-operation, Conflict and Control

\author{
Bill Hebenton
}

and

Terry Thomas 
All rights reserved. No reproduction, copy or transmission of this publication may be made without written permission.

No paragraph of this publication may be reproduced, copied or transmitted save with written permission or in accordance with the provisions of the Copyright, Designs and Patents Act 1988, or under the terms of any licence permitting limited copying issued by the Copyright Licensing Agency, 90 Tottenham Court Road, London W1P 9HE.

Any person who does any unauthorised act in relation to this publication may be liable to criminal prosecution and civil claims for damages.

First published in Great Britain 1995 by

MACMILLAN PRESS LTD

Houndmills, Basingstoke, Hampshire RG21 2XS

and London

Companies and representatives

throughout the world

A catalogue record for this book is available

from the British Library.

ISBN 978-0-333-60007-8

DOI 10.1007/978-1-349-23905-4

ISBN 978-1-349-23905-4 (eBook)

First published in the United States of America 1995 by

Scholarly and Reference Division,

ST. MARTIN'S PRESS, INC.,

175 Fifth Avenue,

New York, N.Y. 10010

ISBN 978-0-312-12423-6

Library of Congress Cataloging-in-Publication Data

Hebenton, Bill, 1955-

Policing Europe : co-operation, conflict, and control / Bill

Hebenton, Terry Thomas.

p. $\mathrm{cm}$.

Includes bibliographical references and index.

ISBN 978-0-312-12423-6

1. Police-European Union countries-International cooperation.

I. Thomas, Terry, 1946- . II. Title.

HV8194.5.A3H43 1995

363.2'094-dc20 
To all our loved ones - past, present and future 
'It must be considered that there is nothing more difficult to carry out, nor more doubtful of success, nor more dangerous to handle, than to initiate a new order of things. For the reformer has enemies in all those who profit by the older order, and only lukewarm defenders in all those who would profit by the new order.'

Niccolò Machiavelli, The Prince 


\section{Contents}

List of Figures ix

List of Tables $\mathrm{x}$

Acknowledgements $\quad$ xi

List of Abbreviations xiii

Introduction 1

1 Contemporary Structures of European Policing 8

2 Police Co-operation: A Crowded Policy Space 38

3 Practical Police Co-operation: Possible Models (1) The Big Three 58

4 Practical Police Co-operation: Possible Models

(2) Other Initiatives

5 Implications of Closer Co-operation for UK

Policing and Criminal Justice

6 Europe: A New Police Terrain

(1) Justifications

7 Europe: A New Police Terrain

(2) Informatization: Police, Technology and Data Protection

8 Policing Europe: Understanding the Future 
Selected Further Reading 207

Organizations and Sources of Information 208

Bibliography 209

Index 227 


\section{List of Figures}

2.1 Europe in Policing Terms

6.1 Trends in Cost-effectiveness of Customs Drug Enforcement Activity, 1979-89

6.2 Trends in Cost-effectiveness of Police Drug Enforcement Activity, 1979-90 


\section{List of Tables}

1.1 Policing Arrangements of European Union States

6.1 Percentage of Foreign Population in Selected OECD Countries

6.2 Asylum-seekers into Selected OECD Countries

6.3 Estimates of Illegally Present Non-nationals in 1991

6.4 Projected Population Growth and Age Structure, 1989-2025 


\section{Acknowledgements}

In the writing of this work we have accumulated numerous intellectual debts. Ken Pease, in his typical way, has always given more than he ever receives and the School of Social Policy at Manchester University continues to provide a reassuring and stimulating environment in which to work. Jon Spencer deserves a special 'thank you' for sharing his illuminating ideas on the situation in Eastern Europe. Also at Manchester, the Henry Fielding Centre for Police Studies and Crime Risk Management responded cheerfully to requests to use their library resources. Martin Baldwin-Edwards, formerly of the University of Manchester (now at the Institute for European Studies, Queen's University Belfast), contributed greatly to our understanding of current immigration debates. Thanks are due to colleagues at Leeds Metropolitan University; Sue Palmer and Paul Schofield for helping create necessary time for writing; Sheila Milner for word processing; Pat Fairfoot, Mary Cousins and Gary Dimmock for offering support in a variety of ways.

Thanks are also due to Alice Mahon MP for helping obtain 'difficult' material and to Eugene McLaughlin for his positive comments at an early stage of this work. At the Home Office we wish to thank Della Cannings.

Next several libraries and their staff deserve mention: the John Rylands University Library of Manchester; Leeds Metropolitan University Library; the Brotherton Library at the University of Leeds; the British Library Document Supply Centre at Boston Spa; and the Research Office of the European Parliament, London. In addition, several networks and their associated publications have contributed to our understanding of policing Europe, principally the Edinburgh University Project Team on European Police Co-operation, the Statewatch group; Platform Fortress Europe network; and our friends, the ever-youthful and enthusiastic Steve Wright 
and Pete Abel of the OMEGA Foundation, Manchester. Joanne Morrison helped in the preparation of the index and Denise Austin produced an excellent draft cover design,

We owe a debt of gratitude to Frances Arnold, our commissioning editor, for her faith in the project and her professionalism. Finally, this has been a truly joint transPennine project and we owe each other a special acknowledgement.

Manchester

Leeds
BILL HEBENTON TERRY THOMAS 


\section{List of Abbreviations}

ACIU Analytical Criminal Intelligence Unit

ACPO Association of Chief Police Officers

AMSS Automatic Message Switching System

ASF

Automated Search Facility

BKA

Bundeskriminalamnt

BND

Bundesnachrichtendienst

BVD

BinnenlandseVeiligheidsdienst

CCC

Customs Co-ordinating Committee

CELAD

Comité Européen de la Lutte Anti-Drogue

CGI-SIE

Comisaria General de Informacion-Servicio de Informacion Exterior

CIREA Centre for Information, Discussion and Exchange on Asylum

CIREFI Centre for Information, Discussion and

Exchange on Immigration

CIS Customs Information System

CNIL Commission Nationale de l'Informatique et des Libertés

COCOLAF Community Co-ordination Committee on Fraud Prevention

COREPER Committee of Permanent Representatives

CRI

Centrale Recherche Informatiedienst

DCPP

Direzione Centrale Della Polizia di

Prevenzione

DEA Drugs Enforcement Agency

DVLC Driving Vehicle Licensing Centre

EDU European Drugs Unit

EFTA

European Free Trade Area

EIS

European Information System

ELO

European Liaison Officer

ELS

European Liaison Section

ENP

European Network for Policewomen/men

EPC

European Political Co-operation 
EPI-Centre European Police Information Centre

FLNC

FPIP.

National Liberation Front of Corsica

HMI

IACP

Fédération Professionelle Indépendente de la Police

ICAO

ICC

ICPC

ICPO

ILO

Her Majesty's Inspectors

International Association of Chiefs of Police

International Civil Aviation Organization

Internal Control Commission

International Criminal Police Commission

International Criminal Police Organization

International Labour Office.

INADPAX International Air Transport Association

Control Working Group on Inadmissible

Passengers

IPEC International Police Exhibition and

Conference

IRP Irish Republican Police

MAG Mutual Assistance Group

MOUs

NCB

Memoranda of Understanding

NCIS

National Central Bureau

NDIU

National Criminal Intelligence Service

NFIU

NTSU

PNC

POTA

PRSU

PSDB

National Drugs Intelligence Unit

National Football Intelligence Unit

National Technical Support Unit

Police National Computer

Prevention of Terrorism Act

Police Requirements Support Unit

PWGOT

$\mathrm{R}$ and $\mathrm{D}$

RCS

RIC

RIO

Police Scientific Development Branch

Police Working Group on Terrorism

Research and Development

Regional Crime Squad

Royal Irish Constabulary

RUC

SCENT

SCODA

SD

Refugees in orbit

Royal Ulster Constabulary

System Customs Enforcement Network

Standing Conference on Drug Abuse

Sicherheitsdierst

SEPAT

SGP

Stupéfiants Europe Plan d'Action à Terme

Syndicat Général de la Police 
SIRENES Supplementary Information Request at the National Entries

SIS Schengen Information System

SOPEMI Continuous Reporting System on Migration

STAR Standiage Arbeidsgruppe Rauschgift

STCIP Service Technique de Coopération

Internationale de Police

TSF Technical Support Function

UCLAF Unité de la Coordination de la Lutte AntiFraude

UISP Union Internationale des Syndicats de Police

USC

Ulster Special Constabulary

WITS

Working Group on International Technical

Support 